\title{
Chronic hepatitis B liver disease in patients living in the Amazon region: $S$ gene mutations and genotypes characterization
}

\author{
Deusilene Vieira ${ }^{1}$, Marie Gauthier ${ }^{2}$, Larissa Deadame de Figueiredo Nicolete ${ }^{1}$, \\ Alcione Oliveira dos Santos ${ }^{1}$, Carina Picelli ${ }^{1}$, Eduardo Honda ${ }^{1}$, Glaucia Paranhos-Baccalà ${ }^{2}$, \\ Guy Vernet ${ }^{2}$, Juan Miguel Villalobos Salcedo ${ }^{1}$

\footnotetext{
${ }^{1}$ Research Center for Tropical Medicine, CEPEM/Tropical Pathology Research Institute, Fiocruz Rondônia, Rio de Janeiro, Brazil ${ }^{2}$ Emerging Pathogens Laboratory, Fondation Mérieux, IFR 128 BioSciences Gerland, Lyon, France Email: 1arissanicolete@gmail.com
}

Received 17 August 2013; revised 27 September 2013; accepted 14 October 2013

Copyright (C) 2013 Deusilene Vieira et al. This is an open access article distributed under the Creative Commons Attribution License, which permits unrestricted use, distribution, and reproduction in any medium, provided the original work is properly cited.

\section{ABSTRACT}

The Amazon region is considered to be a high endemic area for Hepatitis B Virus (HBV) infections, Rondônia state having the highest prevalence. The aim of this study was to identify molecular genotypes and mutations in the $\mathrm{S}$ gene region of $\mathrm{HBV}$ viral genomes from 20 patients using a DNA microarray. Results: Serological tests showed that $88 \%$ of patients were $\mathrm{HBeAg}$ negative, $82 \%$ had anti-HBe antibodies and $33 \%$ were co-infected with Hepatitis Delta Virus. Sixteen percent of the patients were considered cirrhotic, and $11 \%$ have been transfused. The microarray technique identified the genotypes $A$ ( 4 patients), $D$ ( 7 patients) and $F$ ( 7 patients) in 18 samples. Mutations were detected in all 3 genotypes and, overall, A159G, which has been associated with a reduced antigenicity of the virus, was detected most frequently. In genotype A, G119E was the most frequently detected mutation followed by mutations A159G, F134Y, W172C, Y161F and T143S. A159G was detected in all genotype $D$ and $F$ samples followed by mutations T143S, Y161F, N131T, T114S and G119E in genotype D and mutations T143S, Y161F, N131T, T114S and G119E in genotype $F$. Conclusion: The analysis of mutations repartition among genotypes suggests that some of them are preferentially or exclusively associated with genotype A, D or F. This type of tool is adapted for clinical and therapy monitoring of patient as well as for molecular epidemiology research on HBV.

Keywords: Hepatitis B Virus; Mutant Detection; DNA Microarray; Amazon Region

\section{INTRODUCTION}

Non-diagnosed HBV infections in the post vaccination era - such as occult or inactive infections-are a serious public health problem in high endemic areas because they perpetuate transmission and can progress silently to chronic hepatitis, progressive liver disease and hepatocellular carcinoma [1]. Several studies indicate that virus mutations are responsible for this scenario and some studies about the prevalence of mutant genes are emerging $[2,3]$. The HBV genome encodes four major units of transcription and all of them possess mutations that help virus to escape from host immune surveillance promote several diseases or even treatment resistance. The $\mathrm{S}$ gene encodes the viral surface glycoproteins (Hepatitis B surface antigen or HBsAg) [4], that is the main marker of serological diagnosis of HBV infection being the main target for viral neutralization, either by natural or vaccine-induced anti-HBs $[5,6]$. HBV has high genetic polymorphism which due to high error rate of the virus DNA polymerase. Polymorphisms in the PreS/S gene, especially in the "a" determinant region may result in occult infections because the virus containing HBsAg is undetectable by serological tests [7-9]. The HBV can be classified into eight genotypes, from $\mathrm{A}$ to $\mathrm{H}$, that are related to their geographical origin and are themselves divided in sub-genotypes differing by $4 \%-8 \%$ of their sequence [10]. In Brazil, the most recent studies point to the predominance of genotype A and genotype F [11]. The Amazon region, located in Northern-Brazil, is considered to be highly endemic for HBV [12]. Rondônia state (located in the Western part of Amazon) has the greatest HBV prevalence [13].

The aim of this study was to contribute to epidemi- 
ologic studies in this area screening of the most prevalent mutations in the $\mathrm{S}$ gene of Hepatitis virus isolated from chronic HBsAg-positive untreated patients in Porto Velho, Rondônia.

\section{METHODS}

\subsection{Study Area and Population}

The study area is located in western of the Rondônia state in Brazil. We evaluated at the Center for Hepatitis Research Centre for Tropical Medicine (CEPEM Rondônia), adult patients with chronic HBV infection followed at the Hepatology outpatient service of Tropical Medicine Center in Porto Velho. Twenty patients (18 years old or greater) were included in this study, all chronic carriers for HBV. Sex, age, serological status, transaminase levels and histopathological findings are reported in Table 1. None of the patients received treatment for HBV.

\subsection{Consent}

This study was approved by the Brazilian Institutional Ethics Committee of the Centro de Pesquisa em Medicina Tropical (process number 109/10). Written informed consent was obtained from the patient for publication of this manuscript and any accompanying images. A copy of the written consent is available for review by the Editor-in-Chief of this journal

\subsection{DNA Isolation and Amplification}

DNA was extracted from $200 \mu \mathrm{L}$ serum using a commercial method (QIAamp DNA Mini Kit; QIAgen, USA). The DNA was eluted in $100 \mu \mathrm{L}$ water and. stored at $-20^{\circ} \mathrm{C}$

\subsection{Amplification of HBV DNA by Duplex PCR}

The whole HBV DNA genome was amplified by a duplex PCR reaction, which generates 2 amplicons of 1.5 and $1.7 \mathrm{~Kb}$ respectively [14]. Five $\mu \mathrm{L}$ of PCR products were subjected to $1 \%$ agarose gel electrophoresis. Samples that failed to produce the two amplicons by this method were submitted to a second amplification run through a nested PCR, which generates a 740 bp fragment from the overlapping RT and S regions of HBV [2].

\subsection{Labeling and Cleavage}

The amplicons from duplex or nested PCR reactions were cleaved and labeled by heating in acid conditions with biotin [2].

Table 1. Clinical status of patients and HBV genotype.

\begin{tabular}{|c|c|c|c|c|c|c|c|c|c|}
\hline Patient & Sex & Age & HBeAg & Anti-HBe & HBsAg & AST IU/L & ALT IU/L & Cirrhosis & Genotype \\
\hline 1 & M & 38 & - & + & + & 27 & 32 & - & A \\
\hline 2 & M & 29 & - & + & + & 24 & 29 & - & F \\
\hline 3 & M & 18 & - & + & + & 30 & 18 & - & A \\
\hline 4 & M & 35 & + & - & + & 50 & 80 & + & $\mathrm{F}$ \\
\hline 5 & M & 38 & - & + & + & 27 & 21 & - & $\mathrm{D}$ \\
\hline 6 & F & 32 & - & + & + & 12 & 28 & - & $\mathrm{F}$ \\
\hline 7 & M & 20 & - & + & + & 37 & 36 & + & $\mathrm{D}$ \\
\hline 8 & M & 46 & + & - & + & 31 & 6 & + & A \\
\hline 9 & F & 36 & - & + & + & 58 & 37 & - & F \\
\hline 10 & M & 37 & - & + & + & 1,136 & 1,198 & - & $\mathrm{D}$ \\
\hline 11 & M & 60 & - & + & + & 27 & 37 & - & $\mathrm{D}$ \\
\hline 12 & M & 46 & - & + & + & 33 & 25 & - & $\mathrm{D}$ \\
\hline 13 & F & 22 & - & + & + & ND & ND & - & F \\
\hline 14 & M & 50 & - & + & + & 27 & 36 & + & $\mathrm{A}$ \\
\hline 15 & M & 28 & - & + & + & ND & ND & + & $\mathrm{D}$ \\
\hline 16 & $\mathrm{~F}$ & 41 & - & + & + & 27 & 21 & - & $\mathrm{D}$ \\
\hline 17 & M & 49 & - & + & + & ND & ND & + & $\mathrm{F}$ \\
\hline 18 & M & 55 & - & + & + & 118 & 118 & + & $\mathrm{F}$ \\
\hline
\end{tabular}

$(+)$ : positive result; (-): negative result; (ND): no results. 


\subsection{DNA Microarray Hybridization}

PCR products were hybridized on a high-density DNA microarray (designed by Fondation Mérieux and manufactured by Affymetrix, California, USA) which is made of more than 500,000 features (11 $\mu \mathrm{M}$ side length) each containing a specific DNA probe [2].

\subsection{DNA Microarray Analysis}

The array was analyzed using the DNAEM software (bioMérieux, France). The analysis allows the simultaneous identification of the HBV genotype (A to $\mathrm{H}$ ) and the detection of 994 different mutations in S, RT, preC and $\mathrm{BCP}$, Core, $\mathrm{X}$ genes as described by Gauthier et al. (2010) [2].

\subsection{Sequencing of PCR Products}

Samples were sequenced in order to compare with the results obtained with the microarray and confirmation of genotypes, mutations and phylogenetic analysis. Sequencing was performed by GATC Biotech AG (Konstanz, Germany).

\subsection{Serology for $\mathrm{HBV}$}

Serum HBV markers (HBeAg, Anti-HBe, HBsAg, Anti$\mathrm{HBs}$, Anti-HBc) were analyzed using commercial kits (DiaSorin S.p.A, Italy) according to manufacturer specifications. Biochemical tests including levels of aspartate aminotransferase (AST) and alanine aminotransferase (ALT) were determined using Roche's Cobas Mira Plus analyzer. HDV-RNA test in house was used in co-infected patients to defining specific treatment.

\subsection{Statistical Analysis}

The student $t$ test was used to determine the statistical significance of the difference in the number of mutations and the Fischer exact test to compare the presence of individual mutations in patients with and without cirrhosis.

\section{RESULTS}

\subsection{Characterization of the Patients}

The majority ( $88.8 \%$ ) of the 20 patients was male and the average age was 37 years. All of them were HBsAg for more than 6 months. The results of serological tests showed that $88 \%$ were $\mathrm{HBeAg}$ negative and also had anti-HBe antibodies. Patients 5, 10 and 15 are co-infected by Hepatitis Delta Virus (HDV). According to the histopathological findings, $16 \%$ of the patients were considered cirrhotic (Table 1). Samples from 18 patients could be analyzed with the DNA microarray $(90 \%)$ : 8 after whole genome duplex-PCR and 10 after nested-
PCR. DNA could not be amplified in two samples using both protocols and could not be tested on the microarray.

\subsection{S Gene Mutation Results}

The genotypes obtained by microarray presented $100 \%$ of similarity with all samples sequenced. Genotypes A, D and $\mathrm{F}$ were respectively found by the microarray technique in $4(22.2 \%), 7(38.8 \%)$ and $7(38.8 \%)$ of the 18 tested samples. There is no indication that one of the three detected genotypes is associated with cirrhosis (data not shown). In this study it was possible to identify genotypes $\mathrm{A}, \mathrm{D}$ and $\mathrm{F}$ of $\mathrm{HBV}$, prevalent in the state of Rondônia. Twenty-three different mutations in the S region of HBV could be detected in the studied patients (Table 2). Mutations were detected in all 18 samples at 23 different codons (Table 2). Overall genotype F viruses were found more frequently mutated (mean number of mutations/patient: 9.9) than non-F genotypes (mean number 4.9). Genotype A viruses has 4.3 mutations on average and $\mathrm{D}$ viruses have 5.3 mutations.

The patients with cirrhosis $(n=7)$ have 7.3 polymorphisms on average whereas this number is 6.6 in the patients without cirrhosis $(n=11)$. Patients with elevated transaminases $(n=4)$ have a slightly higher number of mutations than those with normal levels ( 8.8 vs 6.3$)$. The 3 patients with HDV-co-infection have a slightly lower number of mutations than those with HBV infection only (5.3 versus 7.1).

As shown in Table 2, the most frequent mutation was A159G which was detected in 16 out of 18 patients $(88.8 \%)$. The two patients with a wild-type amino-acid at that position had a genotype A virus. The G119E and N131T mutations were also detected in the majority of patients $(11 / 18,61.1 \%)$ although the former mutation was more frequent in genotype A $(100 \%)$ than in genotypes $\mathrm{D}$ and $\mathrm{F}$ ( $42.8 \%$ and $57.1 \%$ respectively). Conversely, the N131T mutation was less frequent in genotype A $(25 \%)$ than in genotype D $(57.1 \%)$ and, more evidently, in genotype F (85.7\%). G119E was the most frequently detected mutation in genotype A, A159G in genotype D and A159G and P178Q in genotype F.

Our results are consistent with these studies as all 4 genotype A specimens contain this mutation. In our study, G119E is more often detected in cirrhotic (71.4\%) versus non-cirrhotic (55.4\%) patients.

\section{DISCUSSION}

\subsection{Genotyping Results}

These genotypes have been previously characterized as circulating in Brazil [15-18]. However, a high prevalence of genotype $\mathrm{F}$ proves to be the predominant characteristic of Amerindian populations in the northern region [17]. In our study, genotypes $\mathrm{F}$ and $\mathrm{D}$ were more prevalent 
Table 2. Detection of genotypes and S gene mutations by microarray technique (Gauthier et al. 2010).

\begin{tabular}{|c|c|c|}
\hline Patient & Genotype & Mutations in HBsAg \\
\hline 1 & A & G119E \\
\hline 2 & $\mathrm{~F}$ & I110L, G119E, P120T, N131T, F158L, A159G, W172C, P178Q, F183C,S204N \\
\hline 3 & A & G119E, N131T, F134Y, T143S, A159G, Y161F \\
\hline 4 & $\mathrm{~F}$ & I110L, G119E, N131T, T143A, F158L, A159G, K160N, W172C, P178Q, F183C, M198I, S204N \\
\hline 5 & $\mathrm{D}$ & T143S, A159G \\
\hline 6 & $\mathrm{~F}$ & I110L, G119E, F134L, T143A, F158L, A159G, K160N, P178Q, F183C, S204N \\
\hline 7 & $\mathrm{D}$ & T143S, A159G \\
\hline 8 & A & G119E, F134L, A166G, W172C \\
\hline 9 & $\mathrm{~F}$ & I110L, N131T, T140S, T143S, F158L, A159G, F183C, P178Q, M198I, S204N \\
\hline 10 & $\mathrm{D}$ & N131T, F134Y, C139S, T143S, A159G, Y161F \\
\hline 11 & $\mathrm{D}$ & T114S, N131T, F134Y, T143S, A159G, Y161F, W172C \\
\hline 12 & $\mathrm{D}$ & T114S, G119E, A159G, Y161F, I195M \\
\hline 13 & $\mathrm{~F}$ & C137W, N131T, F134L, G145R, F158L, A159G, K160N, P178Q \\
\hline 14 & A & G119E, F134Y, T143S, A159G, Y161F, W172C \\
\hline 15 & $\mathrm{D}$ & I110L,T114S, G119E, N131T, T143S, A159G, Y161F, P178Q \\
\hline 16 & $\mathrm{D}$ & G119E, P120T, N131T, T143S, A159G, Y161F, P178Q, \\
\hline 17 & $\mathrm{~F}$ & Y100C, I110L, G119E, T143A, N131T, F158L, A159G, K160N, W172C, P178Q, F183C, S204N \\
\hline 18 & $\mathrm{~F}$ & P127L, N131T,A159G, K160N, P178Q, F183C, S204N \\
\hline
\end{tabular}

The most frequent mutations are in bold.

than genotype A, although in previous studies in this region genotypes $\mathrm{A}$ and $\mathrm{D}$ were found to have the highest prevalence [16]. Interestingly, the $7 \mathrm{HBV}$ of genotype F are those which contain the highest average number of mutations in $\mathrm{HBsAg}$, confirming the greater genetic variability of this genotype as suggested by the co-circulation of the three sub-genotypes F1, F2 and F4 in Brazil [11]. Based on these results, it is necessary further study molecular phylogeny of HBV on a greater number of patients from state of Rondônia.

\subsection{Mutations Detection in the $S$ Region and Correlation with the Genotype and Clinical Status}

In our sample panel we did not find any correlation between genotype and severity (elevated transaminases and/or cirrhosis) as suggested by different authors $[19,20]$. Some studies demonstrate the importance of investigating amino acid substitutions in $\mathrm{HBs} A g$ since HBV replication occurs mainly in regions where there are amino acid substitutions [21]. There were different mutations in the $\mathrm{S}$ region of $\mathrm{HBV}$ genomes from the patients of our study. The percentage of patients harboring these mutations varied between $5.5 \%$ and $88.8 \%$. However, we do not know if there is an impact of this high number of mutations on the clinical outcome of the patients. Patients with elevated transaminases or with cirrhosis do not have more mutations than others and patients with genotype $\mathrm{F}$ viruses, which show more mutations than viruses of other genotypes, do not show more frequent elevated transaminases or cirrhosis.

The most prevalent mutation in our study was A159G which has been detected in all genotypes $\mathrm{D}$ and $\mathrm{F}$ samples, irrespective of the clinical status of the patients. The mutation has been detected in 2 out of 4 genotype A samples. A159G has been shown to be more common in symptomatic patients [22]. In our study it is present in both cirrhotic and non-cirrhotic patients.

The G119E mutation, which is also frequently encountered in our study, affects the secretion of virion and also the recognition of HBsAg by monoclonal antibody used in commercial assays $[23,24]$. Some studies consider this mutation as linked to genotype A.

The N131T mutation was detected in all genotypes but was more prevalent in genotype $\mathrm{F}$. This conservative mutation is frequently found in gibbon and other primatederived HBV sequences [24]. Several mutations have been found in the majority of genotype $\mathrm{F}$ specimen but were never detected in other genotypes (F158L, K160N, F183C, S204N). The G145R mutation in the major hy- 
drophilic region has been detected in only one sample (genotype F). Several studies have demonstrated the high prevalence of this mutation in Italy, the United Kingdom, the United States, Singapore, Taiwan, Senegal, India, Indonesia and Japan $[8,25,26]$. Studies conducted in Brazil with samples from southwestern Paraná did not find this mutation [25] which is coherent with our own results. The I110L, T143S and F134Y polymorphisms which were detected in our study have been already described (Simmonds \& Midgley 2005). We detected mutations, G119E, G145R, A159G and F183C, which were previously characterized as reducing immune response to HBsAg $[9,21,27]$. However, all samples from our study, including several samples which harbor 2 of the above mutations, were properly diagnosed for HBsAg as shown in Table 1, probably due to the use of kits containing polyclonal antibodies. Our study on HBsAg-positive patients demonstrates that polymorphisms in $\mathrm{S}$ gene occur not only in occult HBV infections and patients with more severe disease. Furthermore, this is the first study to describe $\mathrm{S}$ gene mutations in the Amazon region and that possible will helps in molecular epidemiology of HBV.

\section{ACKNOWLEDGEMENTS}

We would like to thank Kelly Régia Vieira de Oliveira (CEPEM/ IPEPATRO) for sorologic results.

\section{REFERENCES}

[1] Lavanchy, D. (2004) Hepatitis B virus epidemiology, disease burden, treatment, and current and emerging prevention and control measures. Journal of Viral Hepatitis, 11, 97-107. http://dx.doi.org/10.1046/j.1365-2893.2003.00487.x

[2] Gauthier, M., Bonnaud, B., Arsac, M., Lavocat, F., Maisetti, J., Kay, A., et al. (2010) Microarray for hepatitis B virus genotyping and detection of 994 mutations along the genome. Journal of Clinical Microbiology, 48, 42074215. http://dx.doi.org/10.1128/JCM.00344-10

[3] Sticchi, L., Caligiuri, P., Cacciani, R., Alicino, C. and Bruzzone, B. (2013) Epidemiology of HBV S-gene mutants in the Liguria Region, Italy: Implications for surveillance and detection of new escape variants. Human Vaccines \& Immunotherapeutics, 9, 568-571. http://dx.doi.org/10.4161/hv.23236

[4] Kao, J.-H., Liu, C.-J. and Chen, D.-S. (2002) Hepatitis B viral genotypes and lamivudine resistance. Journal of Hepatology, 36, 303-304. http://dx.doi.org/10.1016/S0168-8278(01)00246-X

[5] Lai, C.L., Ratziu, V., Yuen, M.-F. and Poynard, T. (2003) Viral hepatitis B. The Lancet, 362, 2089-2094. http://dx.doi.org/10.1016/S0140-6736(03)15108-2

[6] Schaefer, S. (2007) Hepatitis B virus taxonomy and hepatitis B virus genotypes. World Journal of Gastroenterology, 13, 14-21.
[7] Datta, S., Banerjee, A., Chandra, P.K., Chowdhury, A. and Chakravarty, R. (2006) Genotype, phylogenetic analysis, and transmission pattern of occult hepatitis $\mathrm{B}$ virus (HBV) infection in families of asymptomatic HBsAg carriers. Journal of Medical Virology, 78, 53-59. http://dx.doi.org/10.1002/jmv.20503

[8] Weber, B. (2005) Genetic variability of the S gene of hepatitis B virus: clinical and diagnostic impact. Journal of Clinical Virology: The Official Publication of the Pan American Society for Clinical Virology, 32, 102-112. http://dx.doi.org/10.1016/j.jcv.2004.10.008

[9] François, G., Kew, M., Damme, Van P., Mphahlele, M.J. and Meheus, A. (2001) Mutant hepatitis B viruses: A matter of academic interest only or a problem with farreaching implications? Vaccine, 19, 3799-3815. http://dx.doi.org/10.1016/S0264-410X(01)00108-6

[10] Norder, H., Couroucé, A.-M., Coursaget, P., Echevarria, J.M., Lee, S.-D., Mushahwar, I.K., et al. (2004) Genetic diversity of hepatitis B virus strains derived worldwide: Genotypes, subgenotypes, and HBsAg subtypes. Intervirology, 47, 289-309. http://dx.doi.org/10.1159/000080872

[11] Mello, F.C.A., Souto, F.J.D., Nabuco, L.C., Villela-Nogueira, C.A., Coelho, H.S.M., Franz, H.C.F., et al. (2007) Hepatitis B virus genotypes circulating in Brazil: Molecular characterization of genotype $\mathrm{F}$ isolates. $\mathrm{BMC} \mathrm{Mi-}$ crobiology, 7, 103. http://dx.doi.org/10.1186/1471-2180-7-103

[12] Ferreira, C.T. and Silveira, T.R. (2004) Hepatites virais: Aspectos da epidemiologia e da prevenção. Revista Brasileira de Epidemiologia, 7, 473-487. http://dx.doi.org/10.1590/S1415-790X2004000400010

[13] Katsuragawa, T.H., Cunha, R.P.A., Salcedo, J.M.V., Souza, D.C.A., Oliveira, K.R.V., Gil, L.H.S., et al. (2010) Alta soroprevalência de infecção pelos vírus das hepatites $\mathrm{B}$ e C na região do alto rio Madeira, Porto Velho, Rondônia, Brasil. Revista Pan-Amazônica de Saúde, 1, 91-106. http://dx.doi.org/10.5123/S2176-62232010000200011

[14] Tran, N., Berne, R., Chann, R., Gauthier, M., Martin, D., Armand, M.-A., et al. (2006) European multicenter evaluation of high-density DNA probe arrays for detection of hepatitis B virus resistance mutations and identification of genotypes. Journal of Clinical Microbiology, 44, 2792-2800. http://dx.doi.org/10.1128/JCM.00295-06

[15] Ferreira, R.C., Teles, S.A., Dias, M.A., Tavares, V.R., Silva, S.A., Gomes, S.A., et al. (2006) Hepatitis B virus infection profile in hemodialysis patients in Central Brazil: prevalence, risk factors, and genotypes. Memórias Do Instituto Oswaldo Cruz, 101, 689-692. http://dx.doi.org/10.1590/S0074-02762006000600019

[16] Oliveira, L.C.M. and Pontes, J.P.J. (2010) Frequency of hepatitis B immunity and occupational exposures to body fluids among Brazilian medical students at a public university. Revista Do Instituto de Medicina Tropical de São Paulo no date, 52, 247-252.

[17] Moraes, M.T., Niel, C. and Gomes, S.A. (1999) A polymerase chain reaction-based assay to identify genotype $F$ of hepatitis B virus. Brazilian Journal of Medical and Biological Research, 32, 45-49.

[18] Araujo, N.M., Mello, F.C.A., Yoshida, C.F.T., Niel, C. 
and Gomes, S.A. (2004) High proportion of subgroup A' (genotype A) among Brazilian isolates of Hepatitis B virus. Archives of Virology, 149, 1383-1395. http://dx.doi.org/10.1007/s00705-003-0269-4

[19] Kay, A. and Zoulim, F. (2007) Hepatitis B virus genetic variability and evolution. Virus Research, 127, 164-176. http://dx.doi.org/10.1016/j.virusres.2007.02.021

[20] Schaefer, S. (2005) Hepatitis B virus: Significance of genotypes. Journal of Viral Hepatitis, 12, 111-124. http://dx.doi.org/10.1111/j.1365-2893.2005.00584.X

[21] Wu, C., Zhang, X., Tian, Y., Song, J., Yang, D., Roggendorf, M., et al. (2010) Biological significance of amino acid substitutions in hepatitis B surface antigen (HBsAg) for glycosylation, secretion, antigenicity and immunogenicity of HBsAg and hepatitis $\mathrm{B}$ virus replication. The Journal of General Virology, 91, 483-492. http://dx.doi.org/10.1099/vir.0.012740-0

[22] Ruiz-Tachiquín, M.-E., Valdez-Salazar, H.-A., JuárezBarreto, V., Dehesa-Violante, M., Torres, J., Muñoz-Hernández, O., et al. (2007) Molecular analysis of hepatitis B virus "a" determinant in asymptomatic and symptomatic Mexican carriers. Virology Journal, 4, 6. http://dx.doi.org/10.1186/1743-422X-4-6

[23] Khan, N., Guarnieri, M., Ahn, S.H., Li, J., Zhou, Y.,
Bang, G., et al. (2004) Modulation of hepatitis B virus secretion by naturally occurring mutations in the $\mathrm{S}$ gene. Journal of Virology, 78, 3262-3270. http://dx.doi.org/10.1128/JVI.78.7.3262-3270.2004

[24] Tong, S., Kim, K.-H., Chante, C., Wands, J. and Li, J. (2005) Hepatitis B Virus e Antigen Variants. International Journal of Medical Sciences, 2, 2-7. http://dx.doi.org/10.7150/ijms.2.2

[25] Araujo, N.M., Vianna, C.O.A., Soares, C.C. and Gomes, S.A. (2008) A unique amino acid substitution, L215Q, in the hepatitis B virus small envelope protein of a genotype $F$ isolate that inhibits secretion of hepatitis B virus subviral particles. Intervirology, 51, 81-86. http://dx.doi.org/10.1159/000127430

[26] Oon, C.J., Lim, G.K., Ye, Z., Goh, K.T., Tan, K.L., Yo, S.L., et al. (1995) Molecular epidemiology of hepatitis B virus vaccine variants in Singapore. Vaccine, 13, 699-702. http://dx.doi.org/10.1016/0264-410X(94)00080-7

[27] Ito, K., Qin, Y., Guarnieri, M., Garcia, T., Kwei, K., Mizokami, M., et al. (2005) Impairment of Hepatitis B Virus Virion Secretion by Single-Amino-Acid Substitutions in the Small Envelope Protein and Rescue by a Novel Glycosylation Site. Journal of Virology, 79, 14404-14410. 